\title{
Croton argenteus preparation inhibits initial growth, mitochondrial respiration and increase the oxidative stress from Senna occidentalis seedlings
}

\author{
KATLIN S. RECH ${ }^{1}$, CRISTIANE B. SILVA ${ }^{1}$, JULIANA D. KULIK ${ }^{1}$, JOSIANE F.G. DIAS ${ }^{1}$, \\ SANDRA M.W. ZANIN ${ }^{1}$, VITOR A. KERBER ${ }^{1}$, FERNANDA M.M. OCAMPOS ${ }^{1}$, \\ LUCIANE DALARMI ${ }^{1}$, GEDIR O. SANTOS ${ }^{2}$, EUCLÉSIO SIMIONATTO ${ }^{3}$, \\ CRISTINA P. LIMA ${ }^{1}$, OBDÚLIO G. MIGUEL ${ }^{1}$ and MARILIS D. MIGUEL ${ }^{1}$ \\ ${ }^{1}$ Universidade Federal do Paraná, Departamento de Farmácia, Câmpus do Jardim Botânico, \\ Rua Lothário Meissner, 632, Jardim Botânico, 80210-170 Curitiba, PR, Brasil \\ ${ }^{2}$ Universidade Federal do Paraná, Departamento de Biologia, Câmpus Centro Politécnico, \\ Rua Coronel Francisco Heráclito dos Santos, 100, Jardim das Américas, 81531-980 Curitiba, PR, Brasil \\ ${ }^{3}$ Universidade Estadual de Mato Grosso do Sul, Departamento de Química, Câmpus de Naviraí, \\ Rua Emilio Mascolli, 275, Bairro Centro, 79950-000 Naviraí, MS, Brasil \\ Manuscript received on July 11, 2014; accepted for publication on September 19, 2014
}

\begin{abstract}
Senna ocidentalis is a weed, native to Brazil, considered to infest crops and plantations, and is responsible for yield losses of several crops, particularly soybean. The aim of this work was to evaluate if the Croton argenteus extract and fractions possess phytotoxic activity on S. ocidentalis. The crude ethanolic extract (CEE) and its hexanic (HF), chloroformic (CLF) and ethyl acetate (EAF) fractions were tested in germination, growth, oxidative stress increase, Adenosine triphosphate, L-malate and succinate synthesis. The crude extract and its fractions slowed down the germination of S. ocidentalis and decreased the final percentage of germination. Oxidative stress was also increased in the seedlings, by an increase of catalase, peroxidase, superoxide dismutase, glutathione reductase and lipid peroxidation; and it became clear that the ethyl acetate fraction was more phytotoxic. The results indicate that the crude extract and fractions of C. argenteus compromise the mitochondrial energy metabolism, by the inhibition of mitochondrial ATP production, with a decrease in the production of L-malate and succinate. The ethyl acetate fraction of C. argenteus showed high activity on germination and growth, and these effects take place by means of mitochondrial metabolism alterations and increase the oxidative stress, leading the seedling death.
\end{abstract}

Key words: Alelochemicals, fedegoso, velame branco, ATP synthesis, antioxidant defense.

\section{INTRODUCTION}

Senna occidentalis is an annual herbaceous plant that belongs to the Leguminosae family, popularly known as "fedegoso". It occurs in pastures, in fertile soil or as an invasive of soybean, sorghum and corn crops. The

Correspondence to: Cristiane Bezerra da Silva

E-mail: cris.mpj@gmail.com entire plant is toxic, but its seeds cause spontaneous intoxication in bovine, swine and equine individuals (Barth et al. 1994). Intoxication cases by S. occidentalis occur in the Southern and Southeastern regions of the United States, France, Australia, and in all of Brazil, with the most cases registered in the Southern and Amazonic regions (Rissi et al. 2007, Tokarnia et al. 
2000). Studies have shown that $S$. occidentalis presents resistance to herbicides known as acetolactate synthase inhibitors, with evidences that the resistant biotype continues to increase its distribution and prevalence (Rodrigues and Almeida 2011).

Therefore, the increase in the resistance incidence of weeds to most commercial herbicides has increased the interest for the development of alternative methods for control, based on natural products. Croton argenteus, a Brazilian native species found from the north of the Amazon region to the Midwestern region of Mato Grosso do Sul (Cordeiro et al. 2013) becomes an object of studies for the control of $S$. occidentalis, as it presents dominance in the areas where it develops.

The use of plant species with the ability to suppress other species' growth has been used for weed management in agricultural production (Duke et al. 2000, Khanh et al. 2006, Vyvyan 2002). Numerous substance classes such as phenols, flavonoids and terpenoids have been implicated as substances that may lead to plant growth suppression (Chon et al. 2003, Duke et al. 2000, Kohli et al. 2006).

However, there are few studies involving the mechanism of action. Mitochondrial metabolism is essential for energy production and precursors for the biosynthesis of new cellular structures. An effect on respiratory metabolism may be used as a mechanism of action of natural substances to suppress weed germination and growth (Pergo et al. 2008). Based in these aspects, the aim of this work was to identify if the crude ethanolic extract and fractions of $C$. argenteus present high and selective phytotoxicity in S. occidentalis, by interfering in germination, growth, oxidative stress, mitochondrial ATP synthesis, L-malate and succinate alterations.

\section{MATERIALS AND METHODS}

Plant Collection AND PREPARATION OF THE EXTRACTS

Leaves of the Croton argenteus Forsk. species were collected in November, 2011 in the Pantanal region of Corumbá - MS, and its identification was performed by a specialist in the area; then a sample was deposited in the Botanical Museum of Curitiba (MBM) under the number 36731.

The collected material was dried at room temperature and grinded in a knife/hammer mill (SL 32, Solab, Curitiba, Brazil). The crude ethanolic extract was obtained from $1.5 \mathrm{~kg}$ of the plant material in ethanol, using a Sohxlet apparatus. This was filtered and kept in water bath $\left(65^{\circ} \mathrm{C}\right)$ until total solvent removal. The crude ethanolic extract was used to obtain the fractions by liquid/liquid partition with solvents of different polarities, in the following order: n-hexane, chloroform and ethyl acetate and then, the fractions were dried in water bath as described for the crude ethanolic extract. Germination and initial growth assays were performed from the crude ethanolic extract (CEE) hexanic fraction (HF), chloroformic fraction (CF), ethyl acetate fraction $(\mathrm{EAF})$ and remaining fraction $(\mathrm{RF})$.

\section{DETERMINATION OF PHYTOTOXICITY ACTIVITY}

In the germination and growth bioassays, the CEE and its fractions (HF, CF, EAF, RF) were weighed in an analytical scale (AR 2140-I, Adventure, Curitiba, Brazil) taking in consideration the water content. Stock solutions $\left(1,000 \mu \mathrm{g} \mathrm{mL} \mathrm{mL}^{-1}\right)$ were prepared from the calculated mass for every CEE and fractions, which were dissolved in $0.1 \%$ DMSO (dimethylsulfoxide), obtaining the 500 and $250 \mu \mathrm{g} \mathrm{mL}^{-1}$ by dilution (Dayan et al. 2000). The solutions were buffered with a $10 \mathrm{mM}$ MES (2-morfolinethanesulfonic acid) solution and the $\mathrm{pH}$ was adjusted to 6.0 (Macias et al. 2000) with a $0.1 \mathrm{~mol} \mathrm{~L}^{-1} \mathrm{KOH}$ solution, using a pHmeter (MPA 210, Tecnopar, Curitiba, PR). In these assays the concentrations were seletcted to establish if the phytotoxic effect was dose-dependent (Cândido et al. 2010). The CCE and its fractions (FH, CF, EAF, RF) were assayed with $S$. occidentalis. The bioassays were conducted using Petri dishes (9.0 $\mathrm{cm}$ diameter), containing Whatman filter paper $\mathrm{n}^{\circ}$ 01 , and 30 seeds of the target species were used, 
randomly distributed, with four repetitions for each solution (Brasil 2009), totaling 120 seeds. As control, a DMSO $(0.1 \% \mathrm{v} / \mathrm{v})$ solution was prepared, buffered with MES and with its $\mathrm{pH}$ adjusted to 6.0 .

The Petri dishes containing the seeds were taken to a BOD-type (Biological Organisms Development) germination chamber, model MA-403 (Marconi), under adequate temperature $\left(35{ }^{\circ} \mathrm{C}\right)$ and relative humidity (approximately 80\%) conditions (Brasil 2009). Germination was evaluated on a daily basis, taking as criterion radicular protrusion measuring at least $2.0 \mathrm{~mm}$. The experiment was considered completed when the germination was null for three days in a row.

For the growth bioassays, the seeds were initially germinated in Petri dishes containing filter paper dampened with $5.0 \mathrm{~mL}$ of distilled water. After germination, taking as criterion radicular protrusion measuring at least $2.0 \mathrm{~mm}, 80$ seedlings (four repetitions with 20 seeds) were selected for each treatment, and transferred to Petri dishes containing the treatment solutions, using a similar procedure as that described for the germination bioassays (Macias et al. 2000).

After four days of radicular protrusion, the root and hypocotyl elongation was measured (10 seedlings per plate) using graph paper. Then, these seedlings were dried in an oven at $60{ }^{\circ} \mathrm{C}$ until reaching a constant mass in order to measure alterations in the final dried weight.

The index of germination speed (IVG) was calculated using the formula: IVG $=\Sigma\left(\mathrm{G}_{\mathrm{i}} / \mathrm{N}_{\mathrm{i}}\right)$, (where $G_{i}$ is the number of germinated seeds in the time interval $t_{i-1} \leftrightarrow t_{i}$ and $N_{i}$ is the number of days after sowing), according to Piña-Rodriguez et al. (2004). The growth percentage $(G \%)$ was calculated using the formula: $\mathrm{G} \%=\left(\Sigma \mathrm{n}_{\mathrm{i}} \times \mathrm{N}^{-1}\right)$. 100 , (where $n_{i}$ is the number of germinated seeds in the time interval $t_{i-1} \leftrightarrow t_{i}$ and $\mathrm{N}$ is the number of seed used in each treatment) (Labouriau and Osborn 1984).

\section{OXIDATIVE STRESS EVALUATION}

To verify if the extracts and fractions caused an increase in the oxidative stress in $S$. occidentalis seedlings, the main enzymes related to an increase in oxidative stress were researched: catalase, peroxidase, superoxide dismutase, glutathione reductase and lipid peroxidation.

To evaluate these enzymes, the seedlings subjected to the extracts and fractions were macerated in liquid nitrogen and homogenized in a solution containing $50 \mathrm{mM}$ potassium phosphate buffer $(\mathrm{pH}$ 7.0), $2 \mathrm{mM}$ of EDTA (diaminoethane tetraacetic acid) and $1.0 \%$ PVP (polyvinyl pyrrolidone). The extracts were centrifuged for $20 \mathrm{~min}$ at $4,000 \mathrm{rpm}$ at $4{ }^{\circ} \mathrm{C}$. The supernatant was collected and used as enzymatic extract. The total soluble protein concentration was determined (Bradford 1976). Bovine serum albumin concentrations were used as references.

The catalase (CAT) activity was measured using a reaction medium containing $67 \mathrm{mM}$ potassium phosphate buffer ( $\mathrm{pH}$ 7.0), $10 \mathrm{mM} \mathrm{H}_{2} \mathrm{O}_{2}$ and 0.1-0.4 mg protein of enzyme extract. The $\mathrm{H}_{2} \mathrm{O}_{2}$ consumption was monitored at $240 \mathrm{~nm}(\varepsilon$, $0.036 \mathrm{mM}^{-1} \mathrm{~cm}^{-1}$ ) (Aebi 1984).

The peroxidase (POD) activity was determined by adding a reaction medium containing $25 \mathrm{mM}$ potassium phosphate buffer ( $\mathrm{pH}$ 6.8), $10 \mathrm{mM} \mathrm{H}_{2} \mathrm{O}_{2}$, $2.6 \mathrm{mM}$ guaiacol solution and 0.1-0.4 mg protein of enzyme extract. Tetraguaicol formation $(\varepsilon, 25.5$ $\mathrm{mM}^{-1} \mathrm{~cm}^{-1}$ ) was measured at $470 \mathrm{~nm}$ (Pütter 1974).

The superoxide dismutase (SOD) activity was estimated (Giannopolitis and Ries 1977). The reaction medium that was used contained a $50 \mathrm{mM}$ potassium phosphate buffer solution ( $\mathrm{pH} 7.8$ ), 6.5 $\mathrm{mM} L$-methionine, $150 \mu \mathrm{M}$ nitro blue tetrazolium (NBT), $4.0 \mu \mathrm{M}$ riboflavin and 0.02-0.1 $\mathrm{mg}$ protein of enzyme extract. The reaction was started using a lamp $(20 \mathrm{~W})$ and the samples were illuminated for $20 \mathrm{~min}$ at $30^{\circ} \mathrm{C}$. One unit of SOD activity (U) was defined as the amount of enzyme needed to cause a $50 \%$ NBT inhibition at $560 \mathrm{~nm}$, and the results were expressed in $\mathrm{U} \mathrm{SOD} \times \mathrm{mg}$ protein ${ }^{-1}$. 
The glutathione reductase activity was measured in a reaction medium containing $50 \mathrm{mM}$ potassium phosphate buffer ( $\mathrm{pH}$ 8.0), 2 mM EDTA, and $0.5 \mathrm{mM}$ oxidated gluthatione (GSSG), $0.15 \mathrm{mM}$ NADPH, 0.1-0.4 mg protein of enzyme extract. The NADPH oxidation rate was monitored at $340 \mathrm{~nm}(\varepsilon$, $6.2 \mathrm{mM}^{-1} \mathrm{~cm}^{-1}$ ) (Foyer and Halliwell 1976).

The lipid peroxidation was determined using a reaction medium containing $0.1 \%$ trichloroacetic acid, 0.5\% tiobarbituric acid and 0.1-0.4 mg protein of enzyme extract (Gomes-Junior et al. 2006). The absorbance was measured at 534 $\mathrm{nm}$ and the enzymatic activity was expressed in percentage of stimulus lipid peroxidation.

PREPARATION OF MitochONDRIAL SUSPENSION

Ten seedlings of $S$. occidentalis, which were taken from the growth assays, were cut into 1.0 centimeter-long segments and placed in approximately two volumes of extraction medium consisting of $0.4 \mathrm{M}$ mannitol, $50 \mathrm{mM}$ Tris- $\mathrm{HCl}$ (pH 7.2), $1.0 \mathrm{mM}$ EDTA, $1.0 \mathrm{mM} \mathrm{MgCl}_{2}, 0.1 \%$ cysteine $(\mathrm{w} / \mathrm{v})$ and $0.5 \%(\mathrm{w} / \mathrm{v})$ fatty acid-free bovine serum albumin (BSA).

The segments were subsequently homogenized and the homogenate was filtered through several layers of cheesecloth and the filtrate was centrifuged at $1.000 \mathrm{rpm}$ for $10 \mathrm{~min}$ after adjusting the $\mathrm{pH}$ to 7.2 with $\mathrm{KOH}$. The supernatant was centrifuged at $20.000 \mathrm{rpm}$ for $10 \mathrm{~min}$. The mitochondrial pellet was suspended in $2.0 \mathrm{ml}$ of a medium containing 0.3 M mannitol, $1.0 \mathrm{mM}$ EDTA, 20mM HEPES $(\mathrm{pH} 7.2)$ and $0.2 \%(\mathrm{w} / \mathrm{v})$ fatty acid-free BSA. The washed mitochondria were subsequently purified on a Percoll ${ }^{\mathrm{TM}}$ gradient (Bracht et al. 2003, Jackson et al. 1979). The resulting mitochondrial pellet, containing approximately $1.9-5.2 \mathrm{mg}$ mitochondrial protein was suspended in a final volume of $1.5 \mathrm{ml}$ of a medium containing $0.3 \mathrm{M}$ mannitol, 1.0 m MEDTA, 20 mM HEPES (pH 7.2) and $0.2 \%(\mathrm{w} / \mathrm{v})$ fatty acid-free BSA. All operations were performed at $0-4{ }^{\circ} \mathrm{C}$.
DETERMINATION OF MITOCHONDRIAL ATP PRODUCTION

Mitochondria from seedlings $\left(0.12-0.36 \mathrm{mg} \mathrm{ml}^{-1}\right)$ were incubated at $25{ }^{\circ} \mathrm{C}$ in the same reaction medium used for oxygen measurements and containing additionally $10 \mathrm{mM}$ L-malate, $10 \mathrm{mM}$ L-glutamate, $300 \mu \mathrm{M} \mathrm{TPP}+$ and $200 \mu \mathrm{M}$ NAD+ (Vianello et al. 1997). The reaction was initiated by the addition of 5.0mM ADP and stopped after 10 min by the addition of $0.3 \mathrm{M}$ perchloric acid.

After centrifugation at $4.000 \mathrm{rpm}$ for 10 min, the supernatant was neutralized with $\mathrm{K}_{2} \mathrm{CO}_{3}$ and the potassium perchlorate was removed by centrifugation at $4.000 \mathrm{rpm}$ for $5 \mathrm{~min}$. In order to exclude the participation of any ATP synthesis independent of oxidative phosphorylation, such as the adenylate kinase dependent ATP synthesis, a control was run in which $10 \mu \mathrm{M}$ antimycin $\mathrm{A}$ was added to the incubation system. The residual amounts of ATP measured in the presence of antimycin A were discounted.

The ATP content of the neutralized extract was determined spectrophotometrically by an enzymatic method using hexokinase (EC 2.7.1.1) and glucose-6 phosphate dehydrogenase (EC 1.1.1.49) (Lamprecht 1974).

DETERMINATION OF L-MALATE DEHYDROGENASE AND

SucCinATE DEHYDROGENASE ACTIVITIES

The succinate dehydrogenase (EC 1.3.5.1) activity was measured using mitochondria isolated from seedlings $(0.12-0.36 \mathrm{mg})$, were added to a reaction medium containing $20 \mathrm{mM}$ succinate, $1.0 \mathrm{mM}$ KCN, 40 mM Hepes (pH 7.5) and 1\% (v/v) Triton $\mathrm{X}-100$. After $1 \mathrm{~min}$, the reaction was initiated by the addition of $10 \mu \mathrm{l}$ of a solution of $0.5 \%(\mathrm{w} / \mathrm{v})$ DCIP and $0.5 \%(\mathrm{w} / \mathrm{v})$ phenazine methosulfate (Singer 1974). The reaction was carried at $25^{\circ} \mathrm{C}$ in a double beam spectrophotometer at $600 \mathrm{~nm}$.

Activity was calculated from the absorbance decrease, using an extinction coefficient for DCIP of $19.1 \mathrm{mM}^{-1} \mathrm{~cm}^{-1}$. The activity of mitochondrial 
malate dehydrogenase (L-malate-NAD+ oxidoreductase; EC 1.1.1.37) was assayed in the freezethawing extract of mitochondria prepared according to the method of Wedding et al. (1976). The reaction medium contained: $100 \mathrm{mM}$ Tris- $\mathrm{HCl}(\mathrm{pH} 7.8), 20$ $\mathrm{mM} \mathrm{MgCl} 2,1 \mathrm{mM}$ EDTA, $0.1 \mathrm{mM}$ NADH and 0.5 $\mathrm{mM}$ oxaloacetate.

The reaction was initiated by the addition of the enzyme source from seedlings $(0.86-2.7 \mathrm{mg}$ protein) and the oxidation of NADH was monitored spectrophotometrically at $340 \mathrm{~nm}$ (Kumar et al. 2000). Activity was calculated from the absorbance decrease, using the extinction coefficient of NADH $\left(6.22 \mathrm{mM}^{-1} \mathrm{~cm}^{-1}\right)$.

\section{DETERMINATION OF MitochONDRIAL ATP PRODUCTION}

Mitochondria from seedlings $(0.6 \mathrm{mg} \mathrm{mL})$ were incubated at $25{ }^{\circ} \mathrm{C}$ in the same reaction medium used for oxygen measurements and containing additionally $10 \mathrm{mM}$ L-malate, $10 \mathrm{mM}$ L-glutamate, $300 \mu \mathrm{M}$ TPP + and $200 \mu \mathrm{M}$ NAD + (Vianello et al. 1997). The reaction was initiated by the addition of $5.0 \mathrm{mM} \mathrm{ADP}$ and stopped after $10 \mathrm{~min}$ by the addition of $0.3 \mathrm{M}$ perchloric acid.

After centrifugation at $4.000 \mathrm{rpm}$ for 10 min, the supernatant was neutralized with $\mathrm{K}_{2} \mathrm{CO}_{3}$ and the potassium perchlorate was removed by centrifugation at $4.000 \mathrm{rpm}$ for $5 \mathrm{~min}$. In order to exclude the participation of any ATP synthesis independent of oxidative phosphorylation, such as the adenylate kinase dependent ATP synthesis, a control was run in which $10 \mu \mathrm{M}$ antimycin A was added to the incubation system. The residual amounts of ATP measured in the presence of antimycin A were discounted.

The ATP content of the neutralized extract was determined spectrophotometrically by an enzymatic method using hexokinase (EC 2.7.1.1) and glucose-6 phosphate dehydrogenase (EC 1.1.1.49) (Lamprecht 1974). In all assays the sample absorbances were measured in a thermo scientific multiscan FC model microplate reader.

\section{STATISTICAL ANALYSIS}

All data were analyzed by variance analysis (ANOVA), and significant differences between the means were identified by the Dunnett test ( $p$ $<0.05$ ). The data was expressed as mean \pm standard error (SE), and the growth results were presented as percentages, with $0 \%$ representing control findings, positive values representing growth stimulum and negative values representing growth inhibition (Macias et al. 2007).

\section{RESULTS}

The crude extract and fractions obtained from $C$. argenteus demonstrated allelopathic activity in $S$. occidentalis, interfering in germination, radicle and hypocotyl growth in laboratory. The CEE and fractions delayed $S$. occidentalis germination, with the most pronounced effects for the EAF (GVI $=20.18$ and 16.06 for the $500 \mu \mathrm{g} \cdot \mathrm{mL}^{-1}$ and 1.000 $\left.\mu \mathrm{g} \cdot \mathrm{mL}^{-1}\right)$, as demonstrated in Table I. Similar to the EAF, the CEE also decreased the percentage of germination, and the EAF and RF caused decreases of $56.5 \%$ and $50 \%$ of final germination, respectively, at the concentration of $1.000 \mu \mathrm{g} \cdot \mathrm{mL}^{-1}$ (Table II).

TABLE I

Effects of Crude ethanolic extract (CEE), Hexane fraction (HF), Chloroform fraction (CLF), Ethyl acetate fraction (EAF) and Remaining fraction (RF) of $C$. argenteus on Germination velocity index (GVI) of $S$. occidentalis in laboratory.

\begin{tabular}{ccccc}
\hline \multicolumn{5}{c}{ Germination Velocity Index (GVI) } \\
\hline $\mathrm{n}=4$ & Controle & $250 \mu \mathrm{g} \mathrm{mL}^{-1}$ & $500 \mu \mathrm{g} \mathrm{mL}^{-1}$ & $1,000 \mu \mathrm{g} \mathrm{mL}^{-1}$ \\
$\mathrm{CEE}^{*}$ & $33.13 \pm 1.67 \mathrm{a}$ & $28.33 \pm 1.97 \mathrm{~b}$ & $21.50 \pm 1.46 \mathrm{~b}$ & $18.07 \mathrm{~b}$ \\
$\mathrm{HF}^{*}$ & $33.13 \pm 1.67 \mathrm{a}$ & $30.38 \pm 0.48 \mathrm{~b}$ & $25.96 \pm 0.82 \mathrm{~b}$ & $24.83 \pm 0.71 \mathrm{~b}$ \\
$\mathrm{CLF}^{*}$ & $33.13 \pm 1.67 \mathrm{a}$ & $31.15 \pm 1.17 \mathrm{~b}$ & $28.04 \pm 1.25 \mathrm{~b}$ & $27.15 \pm 1.14 \mathrm{~b}$ \\
$\mathrm{EAF}^{*}$ & $33.13 \pm 1.67 \mathrm{a}$ & $24.43 \pm 2.70 \mathrm{~b}$ & $20.18 \pm 2.55 \mathrm{~b}$ & $16.06 \pm 0.99 \mathrm{~b}$ \\
$\mathrm{RF}^{*}$ & $33.13 \pm 1.67 \mathrm{a}$ & $26.19 \pm 2.09 \mathrm{~b}$ & $24.17 \pm 1.37 \mathrm{~b}$ & $21.05 \pm 1.18 \mathrm{~b}$ \\
\hline
\end{tabular}

*Results followed by the same letter do not differ statistically $(\mathrm{p}<0.05)$ among themselves, by Dunnett's test.

At the root development, all concentrations affected the initial $S$. occidentalis growth, and the most pronounced inhibitory effect was observed 
TABLE II

Effects of Crude ethanolic extract (CEE), Hexane fraction (HF), Chloroform fraction (CLF), Ethyl acetate fraction (EAF) and Remaining fraction (RF) of $C$. argenteus on Germination percentage (\%G) of S. occidentalis in laboratory.

\begin{tabular}{ccccc}
\hline \multicolumn{4}{c}{ Germination Percentage (\%G) } \\
\hline CEE* $^{*} 100.00 \pm 0.00 \mathrm{a}$ & $65.00 \pm 2.00 \mathrm{~b}$ & $61.00 \pm 2.83 \mathrm{~b}$ & $58.50 \pm 2.52 \mathrm{~b}$ \\
$\mathrm{HF}^{*}$ & $100.00 \pm 0.00 \mathrm{a}$ & $77.50 \pm 1.91 \mathrm{~b}$ & $71.50 \pm 1.00 \mathrm{~b}$ & $62.00 \pm 2.83 \mathrm{~b}$ \\
$\mathrm{CLF}^{*}$ & $100.00 \pm 0.00 \mathrm{a}$ & $78.23 \pm 1.17 \mathrm{~b}$ & $75.44 \pm 1.26 \mathrm{~b}$ & $71.31 \pm 1.24 \mathrm{~b}$ \\
EAF* $^{*} 100.00 \pm 0.00 \mathrm{a}$ & $53.50 \pm 2.83 \mathrm{~b}$ & $50.00 \pm 1.15 \mathrm{~b}$ & $43.50 \pm 1.91 \mathrm{ab}$ \\
RF* $^{*} 100.00 \pm 0.00 \mathrm{a}$ & $55.03 \pm 1.10 \mathrm{~b}$ & $53.11 \pm 0.58 \mathrm{~b}$ & $50.08 \pm 0.04 \mathrm{~b}$ \\
$\mathrm{CEE}^{*} 100.00 \pm 0.00 \mathrm{a}$ & $65.00 \pm 2.00 \mathrm{~b}$ & $61.00 \pm 2.83 \mathrm{~b}$ & $58.50 \pm 2.52 \mathrm{~b}$ \\
\hline
\end{tabular}

* Results followed by the same letter do not differ statistically $(\mathrm{p}<0.05)$ among themselves, by Dunnett's test.

for the EAF (61\% inhibition at $1.000 \mu \mathrm{g} \cdot \mathrm{mL}^{-1}$ concentration) (Fig.1 A). Only the HF and EAF affected the initial hypocotyl growth. The 500 $\mu \mathrm{g} . \mathrm{mL}^{-1}$ and $1.000 \mu \mathrm{g} \cdot \mathrm{mL}^{-1}$ concentrations of the EAF reduced the hypocotyl growth in values greater than $50 \%$ (Fig. 1 B). Total seedling mass also decreased in terms of the CEE and fractions application. The EAF reduced the dry weight in $66 \%$ at the $1.000 \mu \mathrm{g} . \mathrm{mL}^{-1}$ concentration (Fig. $1 \mathrm{C}$ ). Comparing the growth results, we observed that the phytotoxic effects were more pronounced in the root growth. This may have occurred due to absorption and as a consequence the concentration of phytotoxins in the radicular tissues may have been favored by the physical contact of the root with the filter paper, which contains the fractions.

During the oxidative stress assays evaluation, S. occidentalis showed a high sensibility to EAF, with increases in all concentrations. The 1.000 $\mu \mathrm{g} . \mathrm{mL}^{-1}$ concentration intensified the catalase
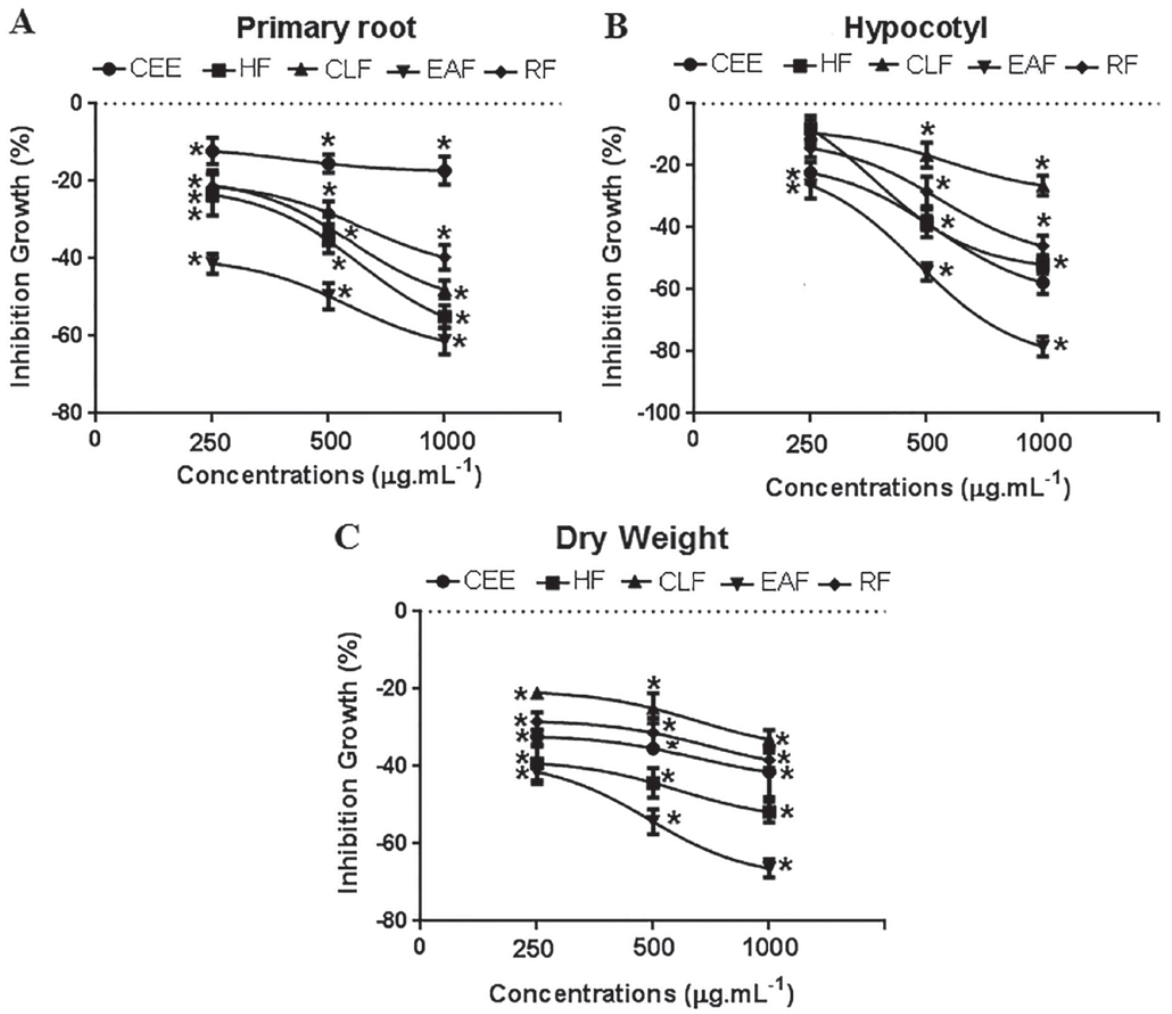

Figure 1 - Effects of Crude ethanolic extract (CEE), Hexane fraction (HF), Chloroform fraction (CLF), Ethyl acetate fraction (EAF) and Remaining fraction (RF) of C. argenteus, on growth of the primary root- (A), hypocotyls- (B) and dry weight- (C) of S. occidentalis. Data expressed in percentage compared to the control. *Statistically different from the control treatment (Dunnett Test, $\mathrm{p}<0.05$ ). 
increase to CEE and other fractions (Fig. 2 A). Plants of $S$. occidentalis were more sensitive to oxidative stress during the growth phase. Plants treated with AEF at $1.000 \mu \mathrm{g} \cdot \mathrm{mL}^{-1}$ stimulated the production of peroxidase $\left(0.32 \mu \mathrm{mol} . \mathrm{min}^{-1}\right)$ and SOD (58 Units. $\mathrm{mg}^{-1}$ ) (Fig. $2 \mathrm{~B}$ and C). The CEE, $\mathrm{HF}$ and EAF also affect the oxidative stress of plants. The glutathione reductase activity (GSH) in $S$. occidentalis seedlings was lower than that of the other oxidative stress-related enzymes. We observed that only the higher concentrations of the extract and fractions were able to induce an increase of this enzyme. HF and EAF showed a marked increase in GSH in $S$. occidentalis seedlings (1.000 $\mu \mathrm{g} . \mathrm{mL}^{-1}$ and $500 \mu \mathrm{g} . \mathrm{mL}^{-1}$ concentrations) as demonstrated in Fig. 2 D.
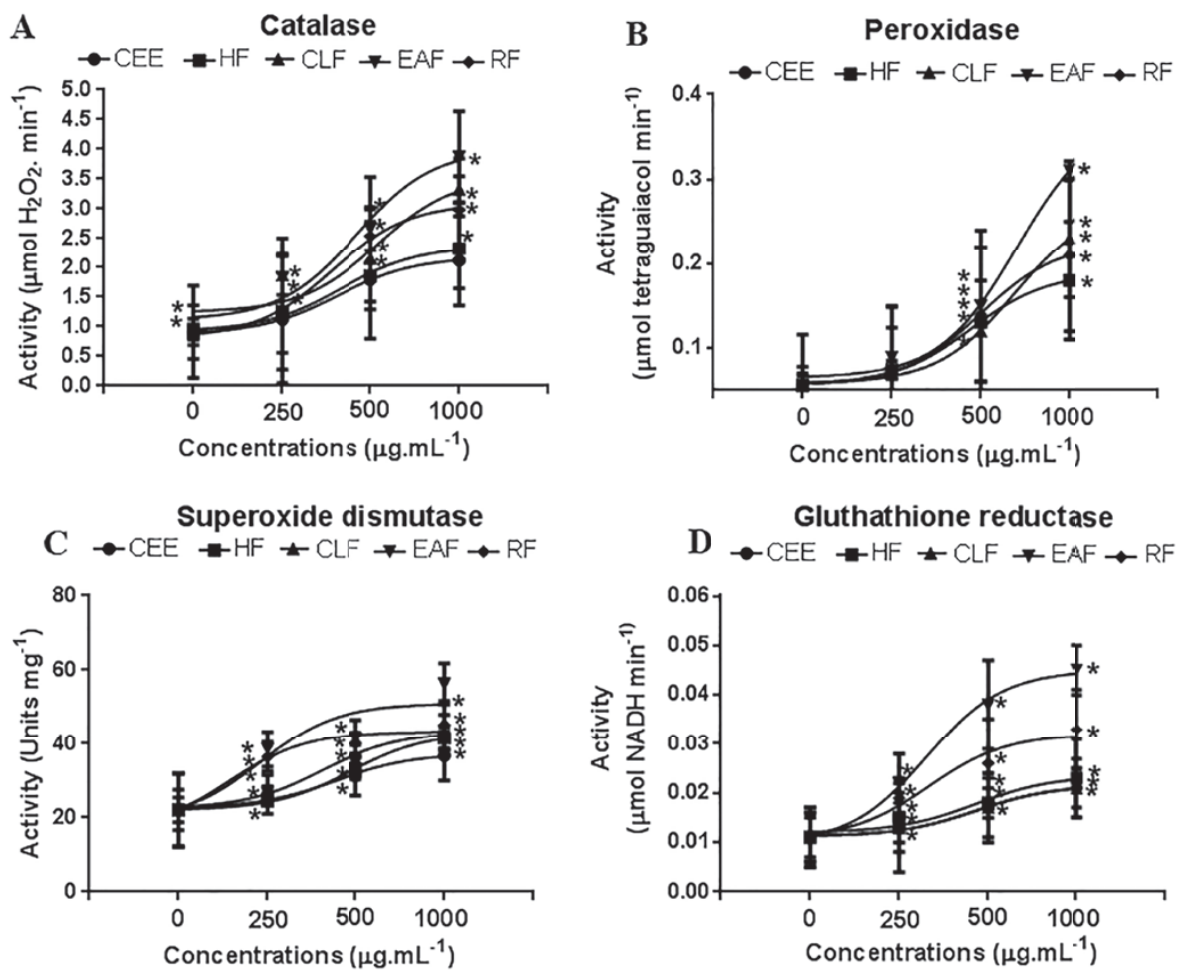

Figure 2 - Effects of Crude ethanolic extract (CEE), hexane fraction (HF), Chloroform fraction (CLF), Ethyl acetate fraction (EAF) and Remaining fraction (RF) of C. argenteus on activities of catalase- (A), peroxidase- (B), superoxide dismutase (SOD)- (C) and glutathione reductase (GSH)- (D) of S. occidentalis. Data expressed in percentage compared to the control. *Statistically different from the control treatment (Dunnett Test, $\mathrm{p}<0.05$ ).

The CEE and fractions increased the lipid peroxidation in $S$. occidentalis in all the tested concentrations. The chloroform and ethyl acetate fractions were more active with stimulus of peroxidation in 50 and $62 \%$, at $1.000 \mu \mathrm{g} \cdot \mathrm{mL}^{-1}$ respectively. (Fig. 3).

The L-malate and succinate synthesis were also lower for the HF and EAF. All this points out that the respiratory process was affected by these fractions, as these enzymes are crucial for mitochondrial respiration regulation (Fig. $4 \mathrm{~A}$ and $\mathrm{B}$ ).

These results are related to the values found in ATP synthesis, demonstrating that HF and EAF are involved in mitochondrial ATP inhibition. Only the $1.000 \mu \mathrm{g} . \mathrm{mL}^{-1}$ concentration of CEE affected ATP synthesis (Fig. 5). 


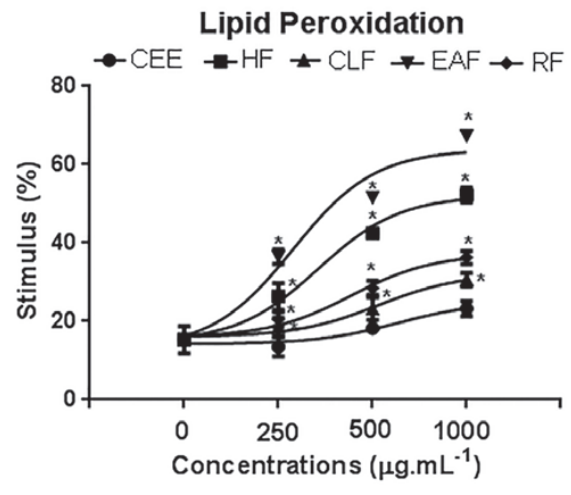

Figure 3 - Effects of Crude ethanolic extract (CEE), Hexane fraction (HF), Chloroform fraction (CLF), Ethyl acetate fraction (EAF) and Remaining fraction (RF) of $C$. argenteus on the stimulus of lipid peroxidation of $S$. occidentalis seedlings. Data expressed in percentage compared to the control. *Statistically different from the control treatment (Dunnett Test, $\mathrm{p}<0.05$ ).
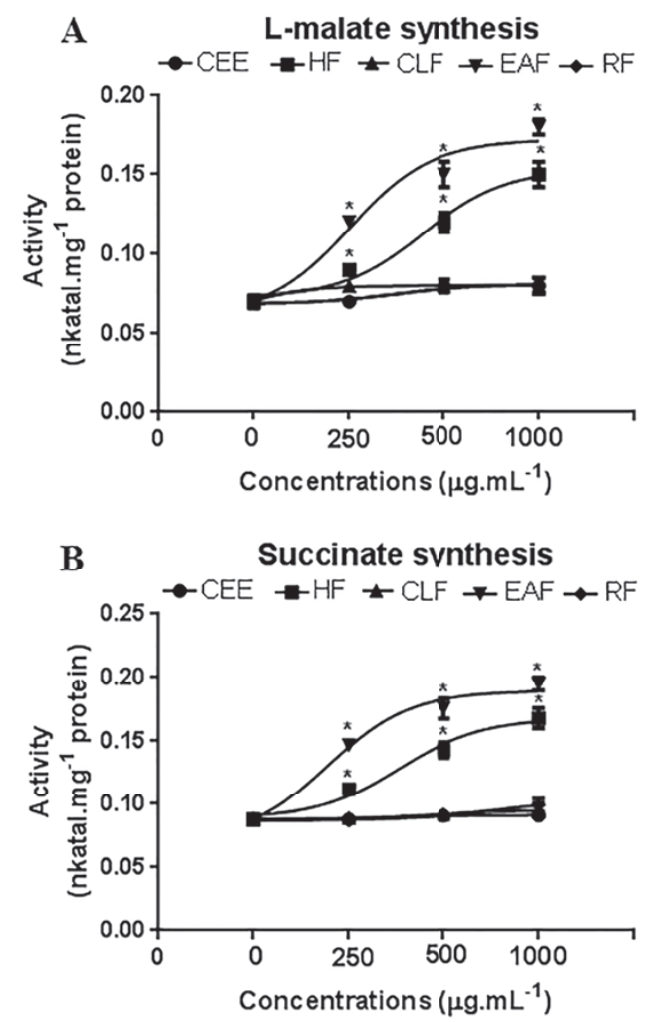

Figure 4 - Effects of Crude ethanolic extract (CEE), Hexane fraction (HF), Chloroform fraction (CLF), Ethyl acetate fraction (EAF) and Remaining fraction (RF) of C. argenteus, on the activities of L-malate dehydrogenase-(A) and succinate dehydrogenase synthesis (B) of S. occidentalis seedlings. Data expressed in percentage compared to the control. *Statistically different from the control treatment (Dunnett Test, $\mathrm{p}<0.05$ ).

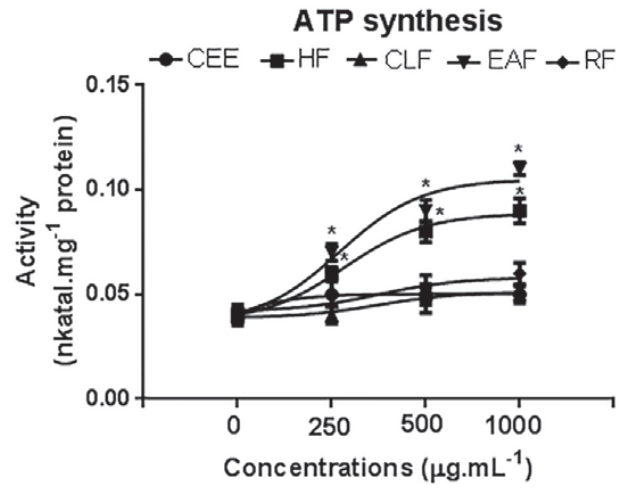

Figure 5 - Effects of Crude ethanolic extract (CEE), Hexane fraction (HF), Chloroform fraction (CLF), Ethyl acetate fraction (EAF) and Remaining fraction (RF) of C. argenteus on synthesis by mitochondria isolated from seedlings of $S$. ocidentalis. Data expressed in percentage compared to the control. *Statistically different from the control treatment (Dunnett Test, $\mathrm{p}<0.05$ ).

\section{DISCUSSION}

The metabolic activity related to the mobilization of reserve nutrients did not increase after germination. This fact was evidenced by a lesser percentage of germinated seeds and a significant delay in the speed of germination. The inhibitory effects persisted during early growing, by inhibition of the primary root and hypocotyl. The aerial part and roots presented different responses to allelochemicals, showing that they affect, to a greater extent the development and/or growth than the germination (Jacobi and Ferreira 1991).

The increase in CAT, POD and SOD activities, CAT in seedlings of $S$. occidentalis and the decrease in $L$-malate, succinate and ATP synthesis suggests that the production of oxygen reactive species is initiated during seeds imbibition. Changes in respiratory activity, was observed by other authors (Kern et al. 2009, Pergo et al. 2008, Pergo and Ishii-Iwamoto 2011).

In this respect, it seems plausible to suggest that catalase, peroxidase and superoxide dismutase increase protection against the $C$. argenteus extract activity; by presenting higher levels, they increase lipid peroxidation and irreversibly damage the cellular membranes (Fleck and Vidal 2001, Hess 2000). 
ROS play ordinary physiological roles in the plant, acting as signaling molecules in many processes, including germination and dormancy breaking (Kwak et al. 2006). The transition of a normal cellular signaling role to toxic signaling with deleterious effects is probably related to homeostasis changes, results from displacements in the balance between ROS production and sweeping.

Hence, the presence of antioxidant substances, which are able to efficiently destroy the superoxide and hydrogen peroxide radicals, such as superoxide dismutase (SOD), catalase (CAT), peroxidases (POD), are necessary for the plants growth (Navrot et al. 2007, Noctor and Foyer 1998).

Independently of the primary mechanisms of the allelochemicals, which can induce an increase the oxidative stress, it is suggested that, the presence of CEE and its fractions leads to an increase in oxidative stress, leaving the seeds / seedlings more vulnerable to dysfunction and cellular death.

The identification of these allelochemicals may contribute to the discovery of natural substances with herbicide potential (Duke et al. 2000, Inderjit and Duke 2003). Indeed, it is known that commercial herbicides cause cellular death by an oxidative stress increase. This is a consequence of interference in the Photosystem II (PSII) flow or in inhibition of antioxidant substances, including carotenoids (Kruse et al. 2006). It is reasonable to suggest that EAF exhibits a great potential to act as herbicide in S. occidentalis by means of its effect in the oxidative stress induction and ATP synthesis inhibition, during the seed germination and seedling early growth.

\section{CONCLUSION}

Under experimental conditions, C. argenteus possess phytotoxic action under $S$. occidentalis as indicated by the increase in oxidative stress, which can be related to dehydrogenases inhibition, as indicated by the low L-malate and succinate dehydrogenase synthesis, and the EAF and HF may be acting in electron transport, leading to inhibition in the ATP production. We can infer that C. argenteus obtained fractions have a selective capacity to suppress $S$. occidentalis germination and growth and can be explored as a natural herbicide to control this species.

\section{ACKNOWLEDGMENTS}

The authors are grateful to Conselho Nacional de Desenvolvimento Científico e Tecnológico (CNPq) and Universidade Federal do Paraná, for the concession of undergraduate scholarships, and to Coordenação de Aperfeiçoamento de Pessoal de Nível Superior (CAPES) for the research scholarship granted for this work.

\section{RESUMO}

Senna ocidentalis é uma planta daninha, nativa do Brasil, sendo considerada infestante de culturas e plantações, e é responsável por perdas de produção de diversas culturas, principalmente de soja. O objetivo deste trabalho foi avaliar se o extrato e frações de Croton argenteus possuem atividade fitotóxica sobre $S$. ocidentalis. O extrato etanólico bruto (EEB) e as frações hexânica (FH), clorofórmio (FCL) e acetato de etila (FAE) foram testados na germinação, crescimento, aumento do estresse oxidativo, síntese de ATP, $L$ - malato e succinato. $\mathrm{O}$ extrato bruto e frações atrasaram a germinação das sementes de $S$. ocidentalis e diminuíram a porcentagem final de germinação. O estresse oxidativo também aumentou nas plântulas tratadas, comprovado pelo aumento na síntese de catalase, peroxidase e superóxido dismutase, glutationa redutase e peroxidação lipídica, sendo evidente que a fração acetato de etila é mais fitotóxica. Os resultados indicam que o extrato bruto e frações de C. argenteus comprometem o metabolismo energético mitocondrial, pela inibição na síntese de ATP mitocondrial, com diminuição na produção de $L$ - malato e succinato. A fração acetato de etila de C. argenteus apresentou alta atividade inibitória sobre a germinação e crescimento, e estes efeitos ocorrem pelas alterações no metabolismo mitocondrial e aumenta o estresse oxidativo, levando a morte das plântulas. 
Palavras-chave: Aleloquímicos, fedegoso, velame branco, síntese de ATP, defesa antioxidante.

\section{REFERENCES}

AEBI H. 1984. Catalase in vitro. Methods in enzymology 105: 121-126.

BARTH AT, KOMmers GD, SAlles MS, Wouters F AND DE BARROS CS. 1994. Coffee Senna (Senna occidentalis) poisoning in cattle in Brazil. Vet Hum Toxicol 36: 541-545.

BRACHT A, SUZUKI-KEMMELMEIERF, SALGUEIRO-PAGADIGORRIA CL, CONSTANTI J, YAMAMOTO NS AND ISHII-IWAMOTO EL. 2003. Enzimas. In: Bracht A and Ishii-Iwamoto EL (Eds), Métodos de laboratório em Bioquímica, Maringá: Manole, p. 103-137.

BRADFORD MM. 1976. A rapid and sensitive method for the quantitation of microgram quantities of protein utilizing the principle of protein-dye binding. Anal Biochem 72: 248-254.

BRASIL. 2009. Regras para a Análise de Sementes. (Ed Brasília), n. 02.

CÂNDIDO ACDS, SCHMIDT V, LAURA VA, FACCENDA O, Hess SC, Simionatto E AND Peres MTLP. 2010. Potencial alelopático da parte aérea de Senna occidentalis (L.) Link (Fabaceae, Caesalpinioideae): bioensaios em laboratório. Acta Bot Bras 24: 235-242.

CHON SU, KIM YM AND LEE JC. 2003. Herbicidal potential and quantification of causative allelochemicals from several Compositae weeds. Weed Res 43: 444-450.

Cordeiro I, Secco R, CARneIro-Torres DS, Lima LRD, CARUZO MBR AND BERRY P. 2013. Croton. Lista de Espécies da Flora do Brasil [Online]. [Accessed 10/02/2013 2013].

DAYAN F, Romagni J AND Duke S. 2000. Investigating the Mode of Action of Natural Phytotoxins. J Chem Ecol 26: 2079-2094.

Duke SO, DAYAN FE, ROMAGNI JG AND RIMANDO AMM 2000. Natural products as sources of herbicides: current status and future trends. Weed Res 40: 99-111.

FLECK NG AND VIDAL RA. 2001. Herbicidas inibidores do fotossistema. In: Vidal RA and Merotto Jr A (Eds), Herbicidologia, Porto Alegre, Rio Grande do Sul: Evangraf, p. 100-112.

FOYER CAND HALLIWELL B. 1976. The presence of glutathione and glutathione reductase in chloroplasts: A proposed role in ascorbic acid metabolism. Planta 133: 21-25.

GIANNOPOLITIS CN AND RIES SK. 1977. Superoxide dismutases: I. Occurrence in higher plants. Plant Physiol 59: 309-314.

Gomes-Junior RA, Moldes CA, Delite FS, Pompeu GB, GRATAO PL, MAZZAFERA P, LEA PJ AND AZEVEDO RA. 2006. Antioxidant metabolism of coffee cell suspension cultures in response to cadmium. Chemosphere 65: 1330-1337.

HESS FD. 2000. Light-dependent herbicides: an overview. Weed Sci 48: 160-170.

INDERJIT S AND DUKE SO. 2003. Ecophysiological aspects of allelopathy. Planta 217: 529-539.
JaCKSON C, Dench JE, Hall DO AND MoOre AL. 1979 Separation of mitochondria from contaminating subcellular structures utilizing silica sol gradient centrifugation. Plant Physiol 64: 150-153.

JACOBI US AND FERREIRA AG. 1991. Efeitos alelopáticos de Mimosa bimucronata (DC). sobre espécies cultivadas. Pesq Agropec Bras 26: 935-943.

Kern KA, Pergo EM, Kagami FL, Arraes LS, Sert MA AND ISHII-IWAMOTO EL. 2009. The phytotoxic effect of exogenous ethanol on Euphorbia heterophylla L. Plant physiology and biochemistry: PPB / Societe francaise de physiologie vegetale 47: 1095-1101.

Khanh TD, Chung IM, TAWATA S AND XuAN TD. 2006. Weed suppression by Passiflora edulis and its potential allelochemicals. Weed Res 46: 296-303.

KOHLI RK, BATISH DR AND SINGH HP. 2006. Allelopathic interactions in agroecosystems. In: Reigosa MV, Pedrol N and Gonzalez L (Eds), Allelopathy: A Physiological Process with Ecological Implications, Netherlands: Springer.

Kruse ND, VidAl RA, Dalmaz C, TREZZI MM AND SiQueIRA I. 2006. Estresse oxidativo em girassol (Helianthus annuus) indica sinergismo para a mistura dos herbicidas metribuzin e clomazone. Planta Daninha 24: 379-390.

KumAR RG, SHAH K AND DUBEy RS. 2000. Salinity induced behavioural changes in malate dehydrogenase and glutamate dehydrogenase activities in rice seedlings of differing salt tolerance. Plant Sci 156: 23-34.

KWAK JM, NGUYEN V AND SChroEder JI. 2006. The role of reactive oxygen species in hormonal responses. Plant Physiol 141: 323-329.

LABOURIAU LG AND OSBORN JH. 1984. Temperature dependence of the germination of tomato seeds. J Therm Biol 9: 285-294.

LAMPRECHT W. 1974. Adenosine-5-triphosphate. Determination with hexokinase and glucose-6-phosphate dehydrogenase. Methods of Enzymatic Analysis 4: 2101-2110.

Macias FA, CASTELlano D AND Molinillo JM. 2000. Search for a standard phytotoxic bioassay for allelochemicals. Selection of standard target species. J Agr Food Chem 48: 2512-2521.

Macias FA, Molinillo JM, VAREla RM and Galindo JC 2007. Allelopathy--a natural alternative for weed control. Pest Manag Sci 63: 327-348.

NAVRot N, RouHIER N, GELHAYE E AND JACQUOT J-P. 2007. Reactive oxygen species generation and antioxidant systems in plant mitochondria. Physiol Plant 129: 185-195.

NOCTOR G AND FOYER CH. 1998. Ascorbate and glutathione: Keeping Active Oxygen Under Control. Annual review of plant physiology and plant molecular biology 49: 249-279.

Pergo EM, Abrahim D, SoAres da Silva PC, Kern KA, DA SILVA LJ, Voll E AND ISHII-IWAMOTO EL. 2008. Bidens pilosa L. exhibits high sensitivity to coumarin in comparison with three other weed species. J Chem Ecol 34: 499-507. 
Pergo EM AND IshiI-IWAmoto EL. 2011. Changes in energy metabolism and antioxidant defense systems during seed germination of the weed species Ipomoea triloba L. and the responses to allelochemicals. J Chem Ecol 37: 500-513.

Piña-Rodriguez FCM, Figliolia MB AND PeiXoto MC. 2004. Testes de Qualidade. In: Ferreira AG and Borghetti F (Eds). Germinação: do básico ao aplicado. Porto Alegre: Ed. Artmed, p. 251-262.

PÜTTER J. 1974. Peroxidases. In: Bergmeyer HU (Ed), Methods of Enzymatic Analysis (Second Edition): Academic Press, p. 685-690.

Rissi DR, RECH RR, Pierezan F, Gabriel AL, Trost ME, BRUM JS, KOMMERS GD AND BARROS CSL. 2007. Intoxicações por plantas e micotoxinas associadas a plantas em bovinos no Rio Grande do Sul: 461 casos. Pesq Vet Bras 27: 261-268.

Rodrigues BN AND AlmeIDA FS. 2011. Guia de herbicidas. Londrina, 697 p.
SINGER TP. 1974. Determination of the activity of succinate, $\mathrm{NADH}$, choline, and alpha-glycerophosphate dehydrogenases. Method Biochem Anal 22: 123-175.

TOKARnia CH, DÖBEREINER J AND PEIXOTo PV. 2000. Plantas tóxicas do Brasil. In: Tokarnia $\mathrm{CH}$, Döbereiner $\mathrm{J}$ and Peixoto PV. Editora Helianthus, Rio de Janeiro, 310 p.

Vianello A, Braidot E, Petrussa E AND Macri F. 1997. ATP synthesis driven by alpha-keto acid-stimulated alternative oxidase in pea leaf mitochondria. Plant Cell Physiol 38: 1368-1374.

VYVYAN JR. 2002. Allelochemicals as leads for new herbicides and agrochemicals. Tetrahedron 58: 1631-1646.

WEDDING RT, BLACK MK AND PAP D. 1976. Malate Dehydrogenase and NAD Malic Enzyme in the Oxidation of Malate by Sweet Potato Mitochondria. Plant physiol 58: $740-743$. 
